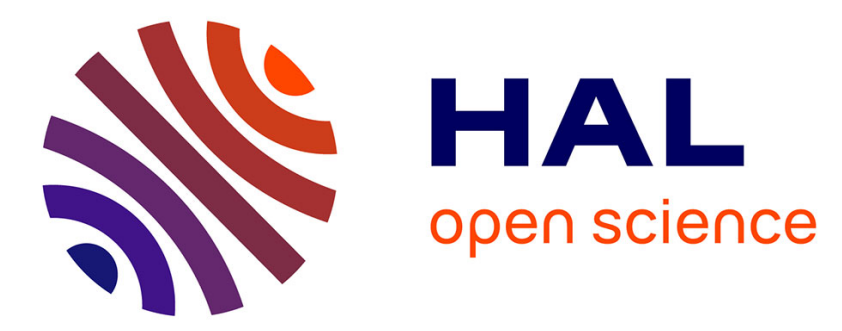

\title{
A positive association between a polymorphism in the HTR2B gene and cocaine-crack in a French Caribbean population
}

Jérôme Lacoste, Sandrine Lamy, Nicolas Ramoz, Nicolas Ballon, Louis Jehel, Luc Maroteaux, Florence Thibaut

\section{To cite this version:}

Jérôme Lacoste, Sandrine Lamy, Nicolas Ramoz, Nicolas Ballon, Louis Jehel, et al.. A positive association between a polymorphism in the HTR2B gene and cocaine-crack in a French Caribbean population. World Journal of Biological Psychiatry, 2020, 21 (10), pp.784-789. 10.1080/15622975.2018.1563721 . hal-01971860

\section{HAL Id: hal-01971860 https://hal.science/hal-01971860}

Submitted on 7 Jan 2019

HAL is a multi-disciplinary open access archive for the deposit and dissemination of scientific research documents, whether they are published or not. The documents may come from teaching and research institutions in France or abroad, or from public or private research centers.
L'archive ouverte pluridisciplinaire HAL, est destinée au dépôt et à la diffusion de documents scientifiques de niveau recherche, publiés ou non, émanant des établissements d'enseignement et de recherche français ou étrangers, des laboratoires publics ou privés. 


\section{A positive association between a polymorphism in the HTR2B gene and cocaine-crack in a French Caribbean population}

Jerome Lacoste ${ }^{1}$, Sandrine Lamy ${ }^{2}$, Nicolas Ramoz ${ }^{3}$, Nicolas Ballon ${ }^{4}$, Louis Jehel ${ }^{5}$, Luc Maroteaux ${ }^{6}$, Florence Thibaut ${ }^{7}$.

${ }^{1}$ Jerome Lacoste MD PhD

CHU Martinique, Department of Psychiatry and Addictology, Fort-de-France, Martinique; CESP/Inserm U1018-Team IPSOM, Paris, France.

ORCID : 0000-0002-4994-1683

Email address: jerome.lacoste@chu-martinique.fr

${ }^{2}$ Sandrine Lamy MD PhD

Department of Addictology, Ramsay-General de Santé, SSR Petit Colmoulins, Harfleur, France

Email address: $\underline{\text { sandrine.lamy74@gmail.com }}$

${ }^{3}$ Nicolas Ramoz $\mathrm{PhD}$

INSERM UMR894-Team 1 Genetic and clinical vulnerability to addictive and psychiatric disorders. Center of Psychiatry and Neuroscience, Paris France

Email address: nicolas.ramoz@inserm.fr

${ }^{4}$ Nicolas BALLON MD PhD

UMR 1253, iBrain, Université de Tours, Inserm, Tours, France

Hôpital Bretonneau CHRU de Tours

E-mail : nicolas.ballon@univ-tours.fr

${ }^{5}$ Louis Jehel MD PhD

Universite des Antilles, Pointe-a-Pitre, Guadeloupe; CESP/Inserm U1018-Team IPSOM, Paris, France; CHU Martinique, Department of Psychiatry and Addictology, Fort-de-France, Martinique.

Email address: louis.jehel@chu-martinique.fr

${ }^{6}$ Luc Maroteaux PhD

INSERM U 839, Paris, 75005, France; UMR-S839 Sorbonne Université, Paris, 75005, France; Institut du Fer à Moulin, Paris, 75005, France.

ORCID : 0000-0002-9499-8603

Email address: luc.maroteaux@upmc.fr

${ }^{7}$ Florence Thibaut corresponding author MD PhD

University Sorbonne Paris-Cité (Faculty of Medicine Paris Descartes), INSERM UMR 894Team1 Center of Psychiatry and Neuroscience, Department of Psychiatry and Addictive Disorders, University Hospital Cochin (site Tarnier), 89 rue d'assas, Paris France

ORCID : 0000-0002-0204-5435

Tel +33158413301 Fax +33158413303

Email address: florence.thibaut@aphp.fr

Manuscript: 3 Tables, 2 Figures, 1 Supplementary figure, 1959 words

Running title: Crack and HTR2B gene 


\begin{abstract}
: 171 words
Objectives: Cocaine dependence has a strong heritability component. This study was aimed to investigate the putative association between the serotonin $2 \mathrm{~B}$ receptor gene (HTR2B), patients with crack use disorders and impulsivity.

Methods: A French Caribbean male population of patients with crack use disorders $(n=80)$ was compared to healthy male controls $(n=60)$. Comorbid ADHD and impulsivity were assessed. Five Single Nucleotide Polymorphisms (SNPs) in the HTR2B gene on chromosome 2 were selected: rs643700, rs6736017, rs1549339, rs17586428 and rs3806545 These five SNPs were chosen to cover most of the linkage disequilibrium (LD) blocks in HTR2B. The French translation of the Baratt Impulsivity Scale BIS-11 was used to evaluate impulsivity. Comorbid ADHD was diagnosed using the Wender Utah Rating Scale-25 item for the Attention Deficit-Hyperactivity Disorder.

Results: We have found a positive association between the rs6736017 polymorphism and crack use disorders in a French Afro-Caribbean male population.

Conclusion: The risk effect of HTR2B rs6736017 appeared to be specific to individuals who are crack users rather than being driven by impulsivity alone or ADHD alone.
\end{abstract}

Keywords: cocaine; crack; HTR2B gene, impulsivity, ADHD. 


\section{Introduction}

Cocaine addiction remains a serious public health concern worldwide. The annual prevalence rate of cocaine use (defined as the number of people aged 15-64 years who have consumed the drug at least once during the last 12 months) is 0.35 worldwide with important regional differences between North America (1.77), Oceania (1.54), Western and Central Europe (1.08) and Asia (0.04) (Peacock et al., 2018). When compared to controls with no history of substance abuse, cocaine and/or crack users exhibited higher levels of impulsiveness (for review Czermainski et al., 2017). In addition, attention deficit-hyperactivity disorders (ADHD) and substance use disorders often coexist in adults, the risk of developing cocaine abuse is two times higher in individuals with (vs. without) ADHD; the prevalence of ADHD is also high among patients with cocaine dependence (20-25\%) (for review Miguel et al., 2016). Using the BIS-11 scale, ADHD patients who asked for treatment of cocaine use disorders, compared with those without ADHD, had higher motor impulsivity (Pérez de los Cobos et al., 2011).

Cocaine dependence has a strong heritability component. Siblings of cocaine-dependent subjects had an estimated relative risk of 1.8 of developing cocaine dependence compared with those without cocaine-dependent siblings (Bierut et al. 1998). A higher rate of concordance was also observed among monozygotic twins relative to dizygotic twins (Kendler et al., 2003). A relatively common stop codon (Q20*) was identified in the serotonin $2 \mathrm{~B}$ receptor gene $(H T R 2 B)$ in a Finnish founder population and it was associated with impulsivity (Bevilacqua et al., 2010). Moreover, Tikkanen et al. (2015) have reported that the presence of the HTR2B Q20* predicted impulsive and aggressive behaviors particularly under the influence of alcohol.

Although crack is derived from cocaine, it has distinct patterns of consumption and potential for addiction (Gossop et al., 1994; Gossop et al., 2006). Yet, there is a lack of studies investigating the genetic factors involved in patients with crack use disorders, whose use is gradually increasing.

This study was aimed to investigate the putative association between the serotonin $2 \mathrm{~B}$ receptor gene (HTR2B), crack-cocaine use disorders and impulsivity in a French Caribbean crack-cocaine male population of patients with crack use disorders as compared to healthy male controls.

\section{Subjects and Methods}

Sixty healthy male controls and eighty French Afro-Caribbean male patients with crack use disorders were included in this study. Participants were diagnosed patients with crack use disorders using DSM-IV-R criteria. Healthy controls were consecutively recruited at the blood transfusion center of Martinique, without lifetime personal and family history of psychiatric disorder, including substance abuse. The clinical evaluations were performed by a psychiatrist. All subjects (patients and controls) were male, African Caribbean, and had at least three African-Caribbean grandparents. Healthy controls and patients with crack use disorders were matched for age.. All subjects agreed to participate in the study and signed an informed consent. Medical and drug use histories, socio-demographic characteristics were reported using self-report and medical files. Personal and family psychiatric history of patients and controls were evaluated by a psychiatrist or a psychologist, blind to the genotyping results and trained to the Diagnostic Interview of Genetic Studies (DIGS). (Nurnberger et al. 1994). The French translation of the Baratt Impulsivity Scale BIS-11 (Patton et al., 1995; Bayle et al., 2000) was used to evaluate impulsivity. A score above 71 indicates a high level of impulsivity (Stanford et al., 2009). Comorbid ADHD was diagnosed using the Wender Utah Rating Scale-25 item for the Attention Deficit-Hyperactivity Disorder 
with a cut off value at 46 (Ward et al., 1993; French translation Baylé et al., 2003). Sensation seeking (using the Zuckerman Sensation-Seeking Scale form V-40 item (Zuckerman et al. 1978; French translation Carton et al., 1990) and comorbid psychiatric disorders (using the MINI (Lecrubier et al., 1997) were also assessed (Table 1). The study was approved by the local Ethics Committee (LEC Sud-Ouest et Outre Mer III; CPP: 2009/96; NCT01025219 (ClinicalTrials.gov).

DNAs were collected from blood or saliva samples. A $4 \mathrm{ml}$ venous blood or $2 \mathrm{ml}$ saliva sample (Oragene DNA OG-500 self-collection kit) was collected from each subject. Genomic DNA was extracted according to standard methods. All SNP in samples were genotyped using the Taqman assays (Thermo Fisher). DNAs were genotyped for HTR2B polymorphisms (Tables 2 and 3). The HTR $2 B$ gene contains 4 exons and 3 introns. As described in Figures 1 and 2 and Tables 2 and 3, five SNPs in the HTR2B gene on chromosome 2 were selected based on the 1000 Genomes project (https://www.ncbi.nlm.nih.gov/variation/tools/1000genomes/) including rs643700, rs6736017, rs1549339, rs17586428 and rs3806545. All five SNPs met the criteria of a call rate of $>95 \%$; minor allele frequency of $>0.05$; and Hardy-Weinberg equilibrium of $p>0.05$. The allele frequencies in our sample were very similar to those of the same ethnicity in the HapMap dataset. These five SNPs were chosen to cover most of the linkage disequilibrium (LD) blocks in HTR2B (Figures 2 and 3). The distribution of the SNPs encompassing HTR2B gene were in Hardy-Weinberg equilibrium.

\section{Statistical analyses}

Data analyses were conducted using chi square, ANOVA, Fisher's exact tests and a general linear model. Fisher's exact test interactions between ADHD or impulsivity (qualitatively) and the association between crack status and polymorphisms were tested. A general linear model was used to test interactions between ADHD or impulsivity (quantitatively) and the association between crack status and polymorphisms. Significance was set at $p<0.05$.

\section{Results}

No differences were observed between controls and patients with crack use disorders for age, sensation seeking or BIS attentional scores. Using the WURS-25, and a cut off score of 46, the prevalence of ADHD among patients with crack use disorders $(71.4 \%, n=40)$ was significantly higher compared with controls $(27.3 \%, n=12)(\mathrm{p}<0.001)$. Using the BIS-11, compared to controls, patients with crack use disorders had a higher level of total, motor and nonplanning impulsivity $(\mathrm{p}<0.001)$ (Table 1$)$. Similarly, using a cut off score of 71 (BIS total $>71$ ), patients with crack use disorders had a significantly higher prevalence of total impulsivity $(21.7 \% \mathrm{n}=13)$ as compared to controls $(3.4 \%, \mathrm{n}=2)(\mathrm{p}<0.004)$. Therefore statistical analyses were adjusted for these variables.

A statistically significant association $(p=0.029)$ was observed between the rs6736017 polymorphism allele $\mathrm{T}$ and patients with crack use disorders (Table 2). The level of significance was even higher when 12 patients with crack use disorders with a comorbidity of schizophrenia or bipolar disorder were excluded from the sample, $\mathrm{p}=0.015$, Odds Ratio 2.99, confident interval of 95\% [1.19-7.49] (Table 3). A corrected p value of 0.075 was carried out for multiple tests, showing a trend for association between the rs6736017*T and crack use disorders. A tendency was observed for rs1549339 polymorphism with patients with crack use disorders (Table 2) but it disappeared when psychiatric comorbidity (schizophrenia or bipolar disorder) was taken into account (Table 3). There was neither interaction between ADHD, crack status and any polymorphism studied (Supplementary Table 1), nor between a high score of impulsiveness, crack status and any polymorphism studied (Supplementary Table 2). Using a general linear model to study the interactions between the scores obtained using the 
BIS-11 and the WURS-25, clinical status $\times H T R 2 B$ genotype interactions were not significant suggesting that the relationship between impulsivity or ADHD and HTR $2 B$ genotype in patients with crack use disorders was not different from that observed in controls (Supplementary Tables $3 \& 4$ ). There was no clinical status $\times H T R 2 B$ genotype interaction for novelty seeking.

\section{Discussion}

We have observed a positive association between the rs6736017 polymorphism (a missense variant located in exon 4 of the HTR2B gene) and crack use disorders in a French AfroCaribbean male population. The risk effect of HTR2B rs6736017 appeared to be specific to patients with crack use disorders rather than being driven by impulsivity or ADHD alone; however these results need replication in larger sample of patients as well as in populations of different genetic backgrounds. The level of impulsiveness and the prevalence of ADHD were actually significantly higher in our population of patients with crack use disorders as compared to controls, but a lack of power may have contributed to the lack of interaction observed. One unsolved question is the putative functional consequence of the rs6736017 polymorphism introducing a Met421/Val substitution at the C-terminal cytoplasmic tail of the 5-HT2B receptor (Supplementary Figure 3), which was not found in any sequenced HTR2B in primates.

Bevilacqua et al. (2010) observed that a stop codon in exon 2 (HTR2B Q20*) led to an interruption in the expression of the $5-\mathrm{HT}_{2 \mathrm{~B}}$ receptor and found that this mutation was associated to impulsive behavior. Among these HTR2B Q20* carriers, temperamental traits resembled a passive-dependent personality profile, and the presence of the HTR2B Q20* predicted impulsive and aggressive behaviors particularly under the influence of alcohol (Tikkanen et al., 2015). These impulsive/aggressive traits have also been found in mice lacking 5- $\mathrm{HT}_{2 \mathrm{~B}}$ receptor gene $\left(H \operatorname{tr} 2 b^{-/}\right)$(Bevilacqua et al., 2010). The HTR2B gene may function by modulating levels of both serotonin and dopamine in brain regions involved in impulsivity (Doly et al., 2008). In agreement witht the fact that, to date, the HTR2B Q20* was exclusively reported in a Finnish founder population $(0.012 \%$ of the population) (Bevilacqua et al., 2010), we have not found this stop codon in our population. Furthermore, a recent genome-wide association study (GWAS) of physical aggression occurring under the influence of cannabis in African Americans implicated the HTR2B-rs17440378 TT genotype, which was not previously considered a key cannabis target (Montalvo-Ortiz et al., 2018). Interestingly, treating the 5- $\mathrm{HT}_{2 \mathrm{~B}}$ receptor knockout mice with $\mathrm{THC}$ resulted in increased aggressive behavior in the resident-intruder paradigm, while the opposite effect was observed in wild type mice. Thus, $H T R 2 B$ variation in expression moderates the effects of cannabis on aggression and social interactions (Montalvo-Ortiz et al., 2018). Interestingly, null expression or blockade of $5-\mathrm{HT}_{2 \mathrm{~B}}$ receptors diminishes the reinforcing effects of psychoactive drugs by modulating serotonin and dopamine signaling. The direct effects of HTR2B-rs 17440378 (an intronic polymorphism) on protein function, including regulation is unknown. In general, crack users have a higher level of impulsivity as compared to cannabis users, which means that it may be more difficult to disentangle the respective roles of impulsivity and crack use disorders effects in the association with SNPs, especially in a small sample.

Finally, a major haplotype A-A-G-A (with a frequency of 48\%) for rs6437000-rs10194776rs16827801-rs1549339 (four SNPs located in introns 2 and 3) showed a significant positive association with behavioral-approach-system (BAS) fun seeking in a Han Chinese population (Zhu et al., 2012). BAS fun seeking was also correlated with impulsive behaviors such as drug abuse. Among these four significant SNPs, rs6437000 and rs1549339 were reported to have high linkage disequilibrium with the rare $H T R 2 B$ stop codon Q20*. According to Bevilacqua et al. (2010), HTR2B Q20* was found on a single haplotype background A-G-A- 
(G/A)-A-A for rs6437000-rs4973377-rs1549339-(stop codon)-rs17586428-rs3806545. In contrast, Tsuchimine et al. (2013) have reported that the HTR2B rs10194776 polymorphism was not associated with personality traits, including novelty seeking and impulsivity in healthy Japanese subjects.

The 5- $\mathrm{HT}_{2 \mathrm{~B}}$ receptors are expressed in the adult human brain, especially in the frontal cortex, although at a low level. The recent work by Doly et al. (2017) has shown a stronger locomotor response to cocaine, with a doubling the distance traveled by $5-\mathrm{HT}_{2 \mathrm{~B}}$ receptor mutant mice. The 5- $\mathrm{HT}_{2 \mathrm{~B}}$ receptors involved have been located on dopaminergic neurons, who innervate the nucleus accumbens (NA), a brain area involved in the reward circuit. Their absence decreases the activity of these latter neurons. Paradoxically, the lack of 5-HT $2 \mathrm{~B}$ receptors induces a decrease of dopamine secretion in the NA (Doly et al., 2017). These results indicate that, by binding on 5- $\mathrm{HT}_{2 \mathrm{~B}}$ receptors, serotonin can control the amount of dopamine released by dopaminergic neurons that express the receptor. When these receptors are lacking, this secretion is abnormally low in the NA. Several imaging studies in humans have shown that individuals addicted to cocaine present paradoxically a weaker activation of the NA and a decreased secretion of dopamine in this region (Volkow et al., 2014). Thus, the absence of the $5-\mathrm{HT}_{2 \mathrm{~B}}$ receptor induces a neuronal situation similar to that observed in drug addicts. This similarity between these mutant mice and cocaine addicts suggests that individuals bearing a genetic mutation that invalidates the $5-\mathrm{HT}_{2 \mathrm{~B}}$ receptor or associated to a dysfunction of this receptor could have a greater propensity to become addicted to this drug. Similarly, the chronic 5- $\mathrm{HT}_{2 \mathrm{~B}}$-receptor inhibition makes mice behaving as animals already exposed to cocaine with higher cocaine-induced locomotion. Associated changes in dopaminergic neuron reactivity that includes a local hypodopaminergy, paradoxically and ultimately results in increased cocaine psychostimulant responses without significant change in motivation to the drug whatever the level of impulsivity or hyperactivity observed.

\section{Strengths and limitations of our study}

Our results need replication in larger populations, especially, to conclude that there is an association between genetic variants of HTR2B gene and crack use disorders, independently to ADHD and impulsivity. We calculated a power analysis using sample size calculator and a risk alpha of 0.05 . Considering our sample (80 cases and 60 controls), the percentages of rs6736017*T (0.94 and 0.86 respectively), the estimated power was of $36 \%$. To detect an effect of this magnitude with a power of $80 \%$, one would need to recruit 250 cases and 188 controls. Furthermore, for the interaction studies (with ADHD and impulsivity), the estimated power was of $22 \%$ and $32 \%$ respectively. Nevertherless, we observed a positive association between crack use disorders and a polymorphism located on the HTR2B gene in our sample of 80 male French Afro-Caribbean patients. It should be noted, however, that the SNPs used in this study have different minor allele frequency (MAF) in different ethnic populations based on HapMap Data (http://www.hapmap.org) and that replication studies on populations of different genetic backgrounds are needed. The selection of SNPs was based on a high frequency of the heterozygosity and of the minor allele in Caucasian populations since no African Caribbean population was available at the time of our study

\section{Fundings}

LM's work has been supported by funds from the Centre National de la Recherche Scientifique, the Institut National de la Santé et de la Recherche Médicale, the Sorbonne Universités, and by grants from the Fondation pour la Recherche sur le Cerveau, the Fondation pour la Recherche Médicale "Equipe FRM DEQ2014039529", the French Ministry 
of Research (Agence Nationale pour la Recherche ANR-17-CE16-0008 and the Investissements d'Avenir programme ANR-11-IDEX-0004-02). LM's team is part of the École des Neurosciences de Paris Ile-de-France network and of the Bio-Psy Labex and as such this work was supported by French state funds managed by the ANR within the Investissements d'Avenir programme under reference ANR-11-IDEX-0004-02.

JL's work (CRACK-ANT study) was sponsored by the University Hospital of Martinique for regulatory and ethic submission and was partially supported by a grant from the Clinical Research and Innovation Unit (DRCI) of the University Hospital of Martinique (2010).

\section{Statement of Interest}

Florence Thibaut is Editor-in-Chief of Dialogues in Clinical Neuroscience (the journal receives a grant from Servier). Other authors have no conflict of interest to declare.

\section{Acknowledgements}

The authors thank P Mazeau for editing this manuscript. 
Table 1. Characteristics of patients and controls.

\begin{tabular}{|c|c|c|c|c|c|}
\hline $\begin{array}{c}\text { Clinical } \\
\text { characteristics }\end{array}$ & $\begin{array}{c}\text { Controls } \\
(n=60) \\
\text { Mean+/S.D. }\end{array}$ & $\begin{array}{c}\text { Patients } \\
(\mathrm{n}=80) \\
\text { Mean+/S.D. }\end{array}$ & d.f. & $\mathrm{F}$ & $\mathrm{P}$ value \\
\hline Age & $45.6 \pm 9.2$ & $43.2 \pm 7.5$ & $1 / 117$ & 2.31 & 0.13 \\
\hline WURS 25 & $40.0 \pm 17.7$ & $60.6 \pm 26.6$ & $1 / 98$ & 19.49 & $<0.001 *$ \\
\hline WURS total & $52 . \overline{2}+23$ & $83.0+32.9$ & $1 / 98$ & 27.87 & $<0.001 *$ \\
\hline BIS 11 motor & $6.5 \pm 4.5$ & $22.2+5.8$ & $1 / 117$ & 266.34 & $<0.001^{*}$ \\
\hline $\begin{array}{l}\text { BIS } 11 \\
\text { attentional }\end{array}$ & $17.2 \pm 7.3$ & $17.3 \pm 3.5$ & $1 / 117$ & 0.004 & 0.95 \\
\hline $\begin{array}{c}\text { BIS } 11 \\
\text { nonplanning }\end{array}$ & $13.2+7.6$ & $24.4+5.5$ & $1 / 117$ & 84.48 & $<0.001^{*}$ \\
\hline BIS 11 total & $37 \pm 16.9$ & $63.9+11.9$ & $1 / 117$ & 101.09 & $<0.001 *$ \\
\hline SSS total & $15 . \overline{5}+5.5$ & $16 . \overline{6}+5.6$ & $1 / 119$ & 1.09 & 0.30 \\
\hline
\end{tabular}

An ANOVA was performed to compare patients and controls clinical characteristics.

d.f.: degree of freedom; N: number: S.D.: Standard Deviation

* Significant 
Table 2. Allele frequencies and associations of five candidate SNPs in the HTR2B gene and clinical status (all patients with crack use disorders $(n=80)$ or controls $(n=60)$ ).

\begin{tabular}{cccccc}
\hline Polymorphism & Allele & $\begin{array}{c}\text { Case/Control } \\
\text { counts }\end{array}$ & $\begin{array}{c}\text { Case/Control, } \\
\text { frequencies }\end{array}$ & Chi square & P value \\
\hline rs6736017 & T & $148: 10 / 103: 17$ & $0.94 / 0.86$ & 4.78 & $0.029^{*}$ \\
rs6437000 & C & $48: 11 / 31: 89$ & $0.30 / 0.26$ & 0.59 & 0.44 \\
rs1549339 & G & $64: 90 / 36: 80$ & $0.42 / 0.31$ & 3.14 & 0.07 \\
rs17586428 & A & $111: 47 / 77: 41$ & $0.70 / 0.65$ & 0.78 & 0.38 \\
rs3806545 & A & $107: 49 / 75: 43$ & $0.69 / 0.64$ & 0.76 & 0.38 \\
\hline
\end{tabular}

\section{*Significant}

rs6736017: genetic association $\mathrm{OR}=2.44 \mathrm{CI} 95 \%[1.06-5.55]$

rs1549339: trends of association 
Table 3. Allele frequencies and associations of five candidate SNPs in the HTR2B gene and clinical status (patients with crack use disorders $(n=68)$ or controls $(n=60)$ ).

\begin{tabular}{cccccc}
\hline Polymorphism & Allele & $\begin{array}{c}\text { Case/Control } \\
\text { counts }\end{array}$ & $\begin{array}{c}\text { Case/Controls, } \\
\text { frequencies }\end{array}$ & $\begin{array}{c}\text { Chi } \\
\text { square }\end{array}$ & P value \\
\hline rs6736017 & $\mathrm{T}$ & $127: 7 / 103: 17$ & $0.95 / 0.86$ & 5.92 & $0.015^{*}$ \\
rs6437000 & $\mathrm{C}$ & $37: 99 / 31: 89$ & $0.27 / 0.26$ & 0.06 & 0.80 \\
rs1549339 & $\mathrm{G}$ & $51: 81 / 36: 80$ & $0.39 / 0.31$ & 1.57 & 0.21 \\
rs17586428 & $\mathrm{A}$ & $91: 43 / 77: 41$ & $0.68 / 0.65$ & 0.2 & 0.65 \\
rs3806545 & $\mathrm{A}$ & $87: 45 / 75: 43$ & $0.66 / 0.64$ & 0.15 & 0.70 \\
\hline
\end{tabular}

*Significant

rs6736017: genetic association $\mathrm{OR}=2.99 \mathrm{CI} 95 \%[1.20-7.50]$ 


\section{References}

Baylé F. J., Krebs M.O., Martin C., Bouvard M. P., Wender P. 2003. French version of Wender Utah rating scale (WURS)]. Can J Psychiatry 48(2):132.

Baylé F., Bourdel M.C., Caci H., Gorwood P., Chignon J.M., Ades J., Lôo H. 2000. Structure factorielle de la traduction française de l'échelle d'impulsivité de Barratt. Can J Psychiatry 45(2):156165.

Bevilacqua L., Doly S., Kaprio J., Yuan Q., Tikkanen R., Paunio T., Zhou Z., Wedenoja J., Maroteaux L., Diaz S., Belmer A., Hodgkinson C. A., Dell'osso L., Suvisaari J., Coccaro E., Rose R.J., Peltonen L., Virkkunen M., Goldman D.A. 2010. population-specific HTR2B stop codon predisposes to severe impulsivity. Nature 468:1061-1066.

Bierut L. J., Dinwiddie S. H., Begleiter H., Crowe R.R., Hesselbrock V., Nurnberger J.I. Jr, Porjesz B., Schuckit M.A., Reich T. 1998. Familial transmission of substance dependence: alcohol, marijuana, cocaine, and habitual smoking: a report from the Collaborative Study on the Genetics of Alcoholism. Arch Gen Psychiatry 55(11):982-988.

Carton S., Bungener C., Montreuil M., Allilaire J.F., Widlocher D., Jouvent R.1990. Le concept de recherche de sensation : traduction et validation de l'échelle de Zuckerman. Psychiatr Psychol 5:39-48.

Czermainski F. R., Willhelm A.R., Santos Á.Z., Pachado M.P., de Almeida R.M. M. 2017. Assessment of inhibitory control in crack and/or cocaine users: a systematic review. Trends Psychiatry Psychother 39(3):216-225.

Dahl J. P., Cubells J.F., Ray R., Weller A.E., Lohoff F.W., Ferraro T.N., Oslin D.W ; Kampman K.M ; Dackis C., Tang Y., Gelernter J., Kranzler H.R., O'Brien C.P., Berrettini W.H. 2006. Analysis of variations in the tryptophan hydroxylase-2 (TPH2) gene in cocaine dependence. Addict Biol 11:76-83.

Doly S., Valjent E; Setola V., Callebert J., Herve D., Launay J.M., Maroteaux L.2008. Serotonin 5-HT2B receptors are required for 3,4 methylenedioxymethamphetamine-induced hyperlocomotion and 5HT release in vivo and in vitro. J Neurosci 28:2933-2940.

Doly S., Quentin E., Eddine R., Tolu S., Fernandez S., Bertran-Gonzalez J., Valjent E., Belmer A., Viñals X., Callebert J. Faure P., Meye F. J., Hervé D., Robledo P., Mameli M., Launay J.M., Maldonado R., Maroteaux L. 2017. Serotonin 2B receptors in mesoaccumbens dopamine pathway regulate cocaine responses. J Neurosci 37:10372-10388.

Gelernter J., Sherva R; Koesterer R., Almasy L., Zhao H., Kranzler H.R, Farrer L. 2014. Genomewide association study of cocaine dependence and related traits: FAM53B identified as a risk gene. Mol Psychiatry 19:717-723.

Gossop M; Manning V., Ridge G. 2006. Concurrent use of alcohol and cocaine : differences in patterns of use and problems among users of crack cocaine and cocaine powder. Alcohol Alcoholism 41(2): 121-125. 
Gossop M., Girffiths P., Powis B., Strang J. 1994. Cocaine: patterns os use, route of administration and severity of dependence. Br J Psychiatry 164(5):660-664.

Kendler K.S., Jacobson K.C., Prescott C.A., Neale M.C.2003. Specificity of genetic and environmental risk factors for use and abuse/dependence of cannabis, cocaine, hallucinogens, sedatives, stimulants, and opiates in male twins. Am J Psychiatry 160(4):687-695.

Lecrubier Y., Sheehan D. V., Weiller E., ,Amorim P., Bonora I. , Harnett K. Sheehan K.H., Janavs J., Dunbar G.C. 1997. The Mini International Neuropsychiatric Interview (MINI). A short diagnostic structured interview: reliability and validity according to the CIDI. Eur Psychiatry 12(5):224-231.

Miguel C.S., Martins P.A., Moleda N., Klein M., Chaim-Avancini T., Gobbo M.A., Alves T.M., Silva M.A., Louzã M.R. 2016. Cognition and impulsivity in adults with attention deficit hyperactivity disorder with and without cocaine and/or crack dependence. Drug Alcohol Depend 160:97-104.

Montalvo-Ortiz J. L., Zhou H., D’Andrea I., Maroteaux L., Lori A., Smith A., Ressler K., Nuñez Y.Z., Farrer L.A., Zhao H., Kranzler H.R., Gelernter J. 2018. Translational studies support a role for serotonin $2 \mathrm{~B}$ receptors in aggression-related cannabis response. Mol Psychiatry Jun 6. doi: 10.1038/s41380-018-0077-6. Epub ahead of print.

Nurnberger Jr JI, Blehar MC, Kaufmann CA, York-Cooler C, Simpson SG, HarkavyFriedman J 1994. Diagnostic interview for genetic studies. Rationale, unique features, and training. NIMH Genetics Initiative. Arch Gen Psychiatry 51: 849-859.

Patton J.H., Stanford M.S., Barratt E.S. 1995. Factor structure of the Barratt Impulsiveness Scale. J Clin Psychology 51(6):768-774.

Peacock A., Leung J., Larney S., Colledge S., Hickman M., Rehm J., Giovino G.A., West R., Hall W., Griffiths P., Ali R., Gowing L., Marsden J., Ferrari A.J., Grebely J., Farrell M., Degenhardt L. 2018. Global statistics on alcohol, tobacco and illicit drug use: 2017 status report. Addiction May 10. doi: 10.1111/add.14234.

Pérez de Los Cobos J., Siñol N., Puerta C., Cantillano V., López Zurita C., Trujols J. 2011. Features and prevalence of patients with probable adult attention deficit hyperactivity disorder who request treatment for cocaine use disorders. Psychiatry Res 185(1-2):205-210.

Stanford M.S., Mathias C.W., Dougherty D.M., Lake S. L., Anderson N E., Patton J.H. 2009. Fifty years of the Barratt Impulsiveness Scale: An update and review. Personality Individual Differences 47: 385-395.

Tikkanen R., Tiihonen J., Rautiainen M.R., Paunio T., Bevilacqua L., Panarsky R., Goldman D., Virkkunen M. 2015. Impulsive alcohol-related risk-behavior and emotional dysregulation among individuals with a serotonin 2B receptor stop codon. Transl Psychiatry 5:e681.

Tsuchimine S., Taniguchi T., Sugawara N., Kaneda A., Yasui-Furukori N. 2013. No association between a polymorphism in the serotonin receptor 2B (HTR2B) gene and personality traits in healthy Japanese subjects. Neuropsychobiology 68(1):59-62. 
Volkow N.D., Tomasi D., Wang G.J., Logan J., Alexoff D. L., Jayne M., Fowler J. S., Wong C., Yin P., and Du C. 2014. Stimulant-induced dopamine increases are markedly blunted in active cocaine abusers. Mol Psychiatry 19:1037-1043.

Ward M.F., Wender P.H., Reimherr F.W. 1993. The Wender Utah Rating Scale: An aid in the retrospective diagnosis of childhood Attention Deficit Hyperactivity Disorder. Am J Psychiatry 150:885-890.

Zhu B., Chen C., Moyzis R.K., Dong Q., Chen C., He Q., Li J., Lei X., Lin C. 2012. Association between the HTR2B gene and the personality trait of fun seeking. Personality Individual Differences 53:1029-1033.

Zuckerman M., Eysenck S.B.G., Eysenck H.J. 1978. Sensation seeking in England and America : cross-cultural, age and sex comparisons. J Consult Clin Psychol 46:139-149. 


\section{Legends}

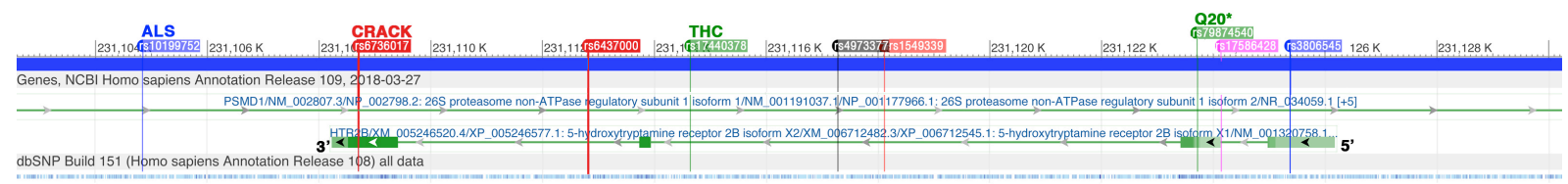

Suppl Figure 1: $H T R 2 B$ gene organization with SNPs position. This is is a schematic representation of $H T R 2 B$ gene with the positions of SNPs, including these genotyped in this study, and SNPs previously associated with disorders

THC: cannabis; Q20*: stop codon in exon 2 (HTR2B); ALS: amyotrophic lateral sclerosis

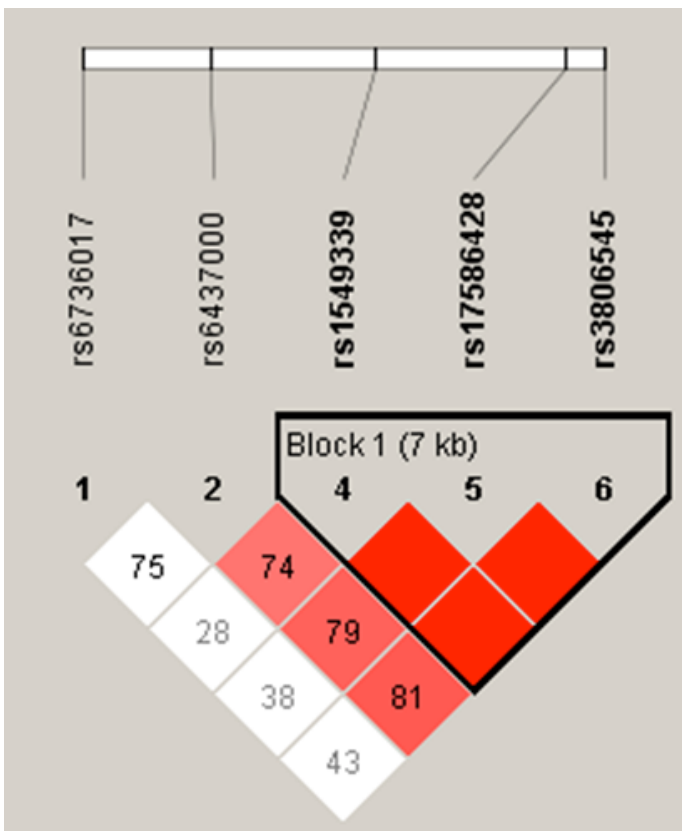

Suppl Figure 2: Haploview image showing the LD colors of D' observed in our study for the genotyped SNPs. We can observed the presence of an haplotype block in 5' part of the $H T R 2 B$ gene

Kb:kilobases; rs: polymorphisms

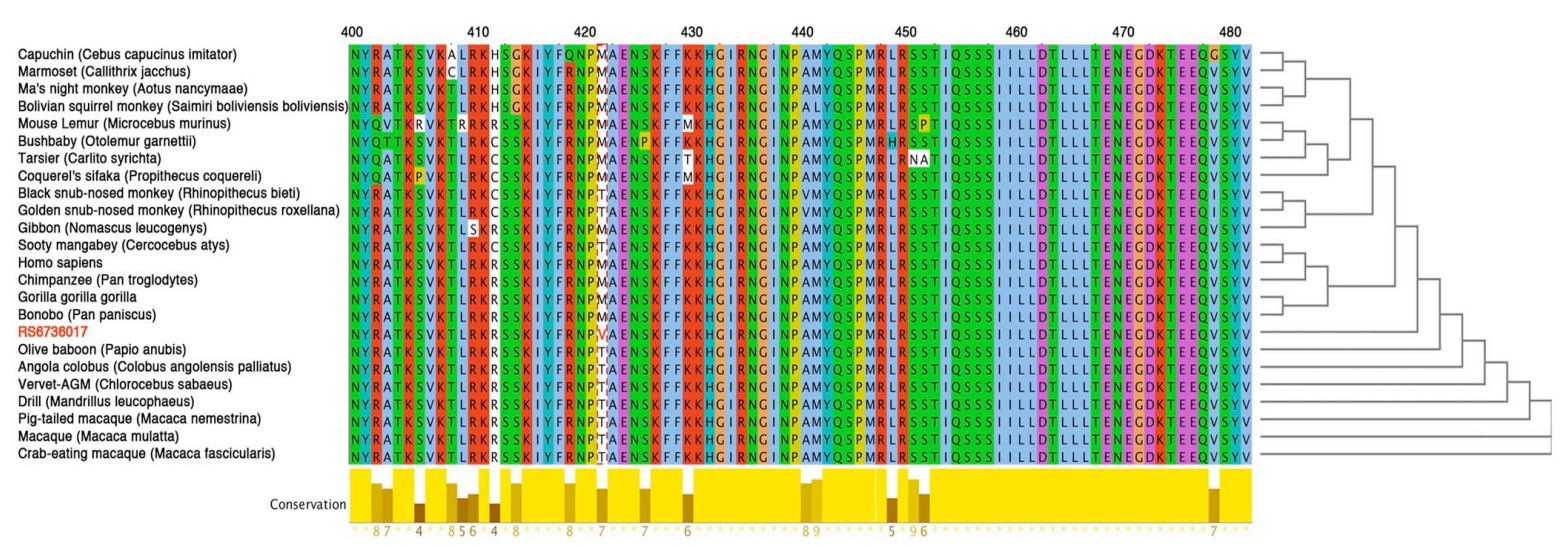

Suppl Figure 3: Clustal W alignment of the C-terminal cytoplasmic tail of primate 5- $\mathrm{HT}_{2 \mathrm{~B}}$ receptors showing the unique presence of a hydrophobic residue (Val) of rs 6736017 polymorphism in place of a Met or Thr in other primates. 


\begin{tabular}{|l|c|c|c|c|c|c|}
\hline SNP & Allele & $\begin{array}{c}\text { Controls } \\
\mathrm{N}=60 \\
\%\end{array}$ & $\begin{array}{c}\text { Crack+ADHD* } \\
\mathrm{N}=40 \\
\%\end{array}$ & P value & $\begin{array}{c}\text { Crack+ADHD** } \\
\mathrm{N}=36 \\
\%\end{array}$ & $\begin{array}{c}\text { P } \\
\text { value }\end{array}$ \\
\hline rs643700 & $\mathrm{A}$ & 89 & 56 & 0.313 & 50 & 0.507 \\
\hline & & $74.2 \%$ & $70,00 \%$ & & $69.4 \%$ & \\
\hline & $\mathrm{C}$ & 31 & 24 & & 22 & \\
\hline & & $25.8 \%$ & $30,00 \%$ & & $30.6 \%$ & \\
\hline rs6736017 & $\mathrm{C}$ & 17 & 6 & 0.121 & 4 & 0.094 \\
\hline & & $14.2 \%$ & $7.7 \%$ & & $5.7 \%$ & \\
\hline & $\mathrm{T}$ & 103 & 72 & & 66 & \\
\hline & & $85.8 \%$ & $92.3 \%$ & & $94.3 \%$ & \\
\hline rs1549339 & $\mathrm{A}$ & 80 & 47 & 0.194 & 43 & 0.337 \\
\hline & & $69,00 \%$ & $61.8 \%$ & & $61.4 \%$ & \\
\hline & $\mathrm{G}$ & 36 & 29 & & 27 & \\
\hline & & $31,00 \%$ & $38.2 \%$ & & $38.6 \%$ & \\
\hline & $\mathrm{A}$ & 77 & 56 & 0.211 & 49 & 0.526 \\
\hline & & $65.3 \%$ & $71.8 \%$ & & $70.0 \%$ & \\
\hline & $\mathrm{G}$ & 41 & 22 & & 21 & \\
\hline & & $34.7 \%$ & $28.2 \%$ & & $30.0 \%$ & \\
\hline & $\mathrm{A}$ & 75 & 56 & 0.148 & 49 & 0.427 \\
\hline & & $63.6 \%$ & $71.8 \%$ & & $70.0 \%$ & \\
\hline & $\mathrm{C}$ & 43 & 22 & & 21 & \\
\hline & & $36.4 \%$ & $28.2 \%$ & & $30.0 \%$ & \\
\hline & & & & & \\
\hline
\end{tabular}

\section{Supplementary Table 1.}

No association was observed between SNPs and ADHD in patients with crack use disorders compared to controls

N: Number ; SNP: single nucleotide polymorphism ; \%: percentage

* All cases of patients with crack use disorders (Total sample: $\mathrm{N}=80$ )

** Patients with crack use disorders without comorbid schizophrenia or bipolar disorder (Total sample: $\mathrm{N}=68$ ) 


\begin{tabular}{|c|c|c|c|c|c|c|}
\hline SNP & Allele & $\begin{array}{c}\text { Controls } \\
\mathrm{N}=60 \\
\%\end{array}$ & $\begin{array}{c}\text { Crack+BIS11 } \geq 50^{*} \\
\mathrm{~N}=54 \\
\%\end{array}$ & $P$ value & $\begin{array}{c}\text { Crack+BIS11 } \geq 50 * * \\
\mathrm{~N}=46 \\
\%\end{array}$ & $\begin{array}{c}P \\
\text { value }\end{array}$ \\
\hline \multirow{4}{*}{ rs643700 } & A & 89 & 77 & 0.368 & 70 & 0.873 \\
\hline & & $74.2 \%$ & $71.3 \%$ & & $76.1 \%$ & \\
\hline & $C$ & 31 & 31 & & 22 & \\
\hline & & $25.8 \%$ & $28.7 \%$ & & $23.9 \%$ & \\
\hline \multirow[t]{4}{*}{ rs6736017 } & $C$ & 17 & 7 & 0.084 & 5 & 0.067 \\
\hline & & $14.2 \%$ & $6.6 \%$ & & $5.6 \%$ & \\
\hline & $\mathrm{T}$ & 103 & 99 & & 85 & \\
\hline & & $85.8 \%$ & $93.4 \%$ & & $94.4 \%$ & \\
\hline \multirow[t]{4}{*}{ rs1549339 } & $A$ & 80 & 63 & 0.123 & 57 & 0.457 \\
\hline & & $69,00 \%$ & $60.6 \%$ & & $63.3 \%$ & \\
\hline & G & 36 & 41 & & 33 & \\
\hline & & $31,00 \%$ & $39.4 \%$ & & $36.7 \%$ & \\
\hline \multirow[t]{4}{*}{ rs17586428 } & A & 77 & 75 & 0.231 & 62 & 0.656 \\
\hline & & $65.3 \%$ & $70.8 \%$ & & $68.9 \%$ & \\
\hline & G & 41 & 31 & & 28 & \\
\hline & & $34.7 \%$ & $29.2 \%$ & & $31.1 \%$ & \\
\hline \multirow[t]{4}{*}{ rs3806545 } & A & 75 & 74 & 0.198 & 61 & 0.559 \\
\hline & & $63.6 \%$ & $69.8 \%$ & & $67.8 \%$ & \\
\hline & C & 43 & 32 & & 29 & \\
\hline & & $36.4 \%$ & $30.2 \%$ & & $32.2 \%$ & \\
\hline
\end{tabular}

Supplementary Table 2.

No association was observed between SNPs and impulsivity in patients with crack use disorders compared to

controls

Crack use disorders with a BIS $>50$ (medium + high level of impulsivity)

$\mathrm{N}$ : Number ; SNP: single nucleotide polymorphism ; \%: percentage

* All cases of patients with crack use disorders (Total sample: $\mathrm{N}=80$ )

** Patients with crack use disorders without comorbid schizophrenia or bipolar disorder

(Total sample: $\mathrm{N}=68$ ) 


\begin{tabular}{|c|c|c|c|c|c|c|c|c|c|}
\hline \multirow[t]{2}{*}{ SNP } & \multicolumn{2}{|c|}{ corrected model } & \multicolumn{2}{|c|}{ WURS \& SNP } & \multirow[b]{2}{*}{$\mathrm{F}$} & \multirow{2}{*}{$\begin{array}{l}\text { WURS \& CRACK } \\
\text { STATUS } \\
\mathrm{P}\end{array}$} & \multirow[b]{2}{*}{$\mathrm{F}$} & \multirow{2}{*}{$\begin{array}{l}\text { WURS \& SNP } x \\
\text { CRACK STATUS } \\
\mathrm{P}\end{array}$} & \multirow[t]{2}{*}{ adjusted $\mathrm{R}^{2}$} \\
\hline & $\mathrm{F}$ & $P$ & $\mathrm{~F}$ & $P$ & & & & & \\
\hline s643700 & 13.700 & $<0.001$ & 1.126 & 0.290 & 34.795 & $<0.001$ & 0.417 & 0.519 & 0.161 \\
\hline rs6736017 & 12.279 & $<0.001$ & 0.045 & 0.832 & 12.749 & $<0.001$ & 0.056 & 0.814 & 0.147 \\
\hline rs1549339 & 12.369 & $<0.001$ & 0.464 & 0.497 & 28.002 & $<0.001$ & 2.295 & 0.131 & 0.150 \\
\hline rs17586428 & 11.897 & $<0.001$ & 0.297 & 0.586 & 30.319 & $<0.001$ & 0.01 & 0.976 & 0.144 \\
\hline rs3806545 & 12.050 & $<0.001$ & 0.685 & 0.409 & 30.905 & $<0.001$ & 0.00 & 0.998 & 0.145 \\
\hline
\end{tabular}

Supplementary Table 3.

No interaction was observed between WURS-25 score, crack use disorders and any SNP using the general linear model with

WURS-25 score as dependent variable.

$\mathrm{N}=60$ controls and $\mathrm{N}=80$ patients with crack use disorders

P: P value 


\begin{tabular}{|l|l|l|l|l|l|l|l|l|l|}
\hline SNP & corrected model & SNP & \multicolumn{3}{l|}{ CRACK STATUS } & SNP x BIS11 & & adjusted R $^{2}$ \\
\hline & $\mathrm{F}$ & $\mathrm{P}$ & $\mathrm{F}$ & $\mathrm{P}$ & $\mathrm{F}$ & $\mathrm{P}$ & $\mathrm{F}$ & $\mathrm{P}$ & \\
\hline s643700 & 68.431 & $<0.001$ & 1.360 & 0.245 & 159.617 & $<0.001$ & 0.250 & 0.617 & 0.460 \\
\hline rs6736017 & 65.873 & $<0.001$ & 0.231 & 0.631 & 58.870 & $<0.001$ & 0.037 & 0.847 & 0.453 \\
\hline rs1549339 & 66.022 & $<0.001$ & 1.111 & 0.293 & 180.879 & $<0.001$ & 0.019 & 0.890 & 0.460 \\
\hline rs17586428 & 64.746 & $<0.001$ & 0.007 & 0.935 & 179.716 & $<0.001$ & 1.435 & 0.232 & 0.451 \\
\hline rs3806545 & 65.373 & $<0.001$ & 0.155 & 0.695 & 185.259 & $<0.001$ & 2.286 & 0.132 & 0.453 \\
\hline
\end{tabular}

Supplementary Table 4.

No interaction was observed between BIS-11 scores, crack use disorders and any SNP using the general linear model with

BIS-11 score as dependent variable.

$\mathrm{N}=60$ controls and $\mathrm{N}=80$ patients with crack use disorders

P: P value 